Jurnal Pemikiran Sosiologi Volume 7 No. 2, Desember 2020

\title{
Model Ekonomi Pengalaman: Memahami Perilaku Konsumen dan Layanan Konten Berbayar1
}

Muhamad Ferdy Firmansyah ${ }^{2}$

\begin{abstract}
Abstraksi
Dalam penulisan ini akan mendeskripsikan secara kualitatif mengenai model kepuasan individu dalam perspektif ekonomis dengan menggunakan pendekatan konsep ekonomi pengalaman dan ekonomi perilaku secara kualitatif. Metode penelitian yang digunakan adalah konsep teoritisasi data (grounded theory approach) dan melakukan pengembangan terhadap konsep pengkodean berbuka, pengkodean berporos dan pengkodean berpilih untuk memberikan pendekatan kualitatif yang maksimal dalam memahami ekonomi pengalaman. Data yang digunakan adalah data sekunder. Diharapkan dengan penulisan ini akan memberikan perspektif baru mengenai perilaku individu dalam pengalamannya secara rohaniah dan jasmaniah dalam kerangka pemikiran ekonomi.
\end{abstract}

Kata kunci: model ekonomi pengalaman, perilaku konsumen, ekonomi digital, layanan konten berbayar

\begin{abstract}
In this paper, I will describe qualitatively the individual satisfaction model in an economic perspective using a qualitative concept approach to experience economics and behavioral economics qualitatively. The research method used is the concept of theorizing the data (grounded theory approach) and developing the concept of breaking coding, porous coding and selective coding to provide a maximum qualitative approach in understanding the experience economy. The data used is secondary data. It is hoped that this writing will provide a new perspective on the behavior of individuals in their spiritual and physical experiences within an economic framework.
\end{abstract}

Keywords: experience economy, consumer behavior, digital economy, paid content services

\section{A. Pendahuluan}

Perkembangan ilmu sosial semakin pesat berkembang, terutama studi mengenai perilaku sosial (social behavioral). Pendekatan-pendekatan untuk melakukan penelitian dalam ilmu sosial mulai mengarah kepada pembaharuan melalui perkembangan interdisiplin seperti ekonomi publik (bauran ilmu ekonomi dan administrasi publik), sosiologi pembangunan (bauran ilmu sosiologi dan studi pembangunan) bahkan muncul walau dalam literatur yang belum banyak yaitu ekonomi pengalaman (bauran dari ilmu ekonomi, sosiologi dan perilaku konsumen).

Dalam ekonomi pengalaman dicetuskan pertama kali dalam literatur B. Joseph Pine II dan James H. Gilmore (1999) yang mengenalkan konsep mengenai The Experience of Economy: Past, Present and Future. Jauh sebelum itu, studi mengenai perilaku konsumen telah lama berkembang dan menjadi salah satu bahasan studi yang strategis untuk mengidentifikasi keadaan fenomena sosial dalam ekonomi (terutama dalam penggunaannya melalu

\footnotetext{
${ }^{1}$ Untuk kutipan atau sitasi artikel ini: Firmansyah, Muhamad Ferdy. 2020. “Model Ekonomi Pengalaman: Memahami Perilaku Konsumen dan Layanan Konten Berbayar." Jurnal Pemikiran Sosiologi Vol 7 (2): 152-168

${ }^{2}$ Program Studi Ekonomi Pembangunan, Fakultas Ekonomi dan Bisnis, Universitas Siliwangi. Email: muhamadferdy77@gmail.com
} 
segmentasi pasar dalam manajemen). Dalam ekonomi pengalaman, dititikberatkan pada individu yang merupakan makhluk sosial yang akan mendalami suatu pengalaman dan akan memberikan pengorbanan ekonomi atas sumber daya yang dimiliki untuk pengalaman tertentu, begitulah perspektif ekonomi yang digunakan dalam penulisan ini. Ekonomi pengalaman memiliki fokus secara ekonomi bahwa sektor jasa tidak hanya memberikan posisi pengeluaran ekonomi dalam pemenuhan kebutuhan jasa, namun memberikan polarisasi dalam keberlanjutan jasa yang digunakan, itu dipengaruhi diantaranya oleh perilaku, pilihan rasional dan psikologis seorang individu. Unsur ekonomi yang ada pada ekonomi pengalaman yang dipahami sebagai perspektif dasar dalam penulisan ini didukung mengenai konsep sosiologi (interaksi sosial, sosialisasi, internalisasi nilai dan norma serta kelompok sosial) serta konsep perilaku konsumen (secara terbatas sebagai daya dukung variabel dalam penentuan penelitian kualitatif dalam bahasan selanjutnya).

Setidaknya seorang konsumen atau individu (selanjutnya akan digunakan kata 'Individu' agar analisis secara sosiologi dapat lebih mendalam) memiliki beberapa kriteria untuk penilaian dalam pemilihan rasionalitasnya dalam memenuhi kebutuhan ekonominya. Dalam hal pembeliah barang fisik (kasus pembelihan kopi instan) individu didukung oleh faktor jenis kelamin, lama aktivitas dan jam kerja, pendidikan dan informasi (Mizfar \& Sinaga, 2015). Dalam studinya jenis kelamin lebih dominan dalam pemenuhan bauran pilihan rasionalitas pembenlian barang fisik kopi instan. Disamping itu dalam perilaku individu terutama dalam kaitannya memenuhi kebutuhan digital (pengalaman belanja secara digital) faktor kebudayaan, sosial, kepribadian dan psikologis berpengaruh positif dan signifikan dalam online shopping (studi kota Makassar) baik secara simultan dan secara parsial, dan diantara sejumlah faktor tersebut, faktor sosial yang memiliki efek dominan dalam pilihan pengalaman online shopping (Nofri \& Hafifah, 2018).

Pengalaman individu dalam kaitannya mengenai ekonomi pengalaman pun dapat menjadi efek primer untuk aktivitas lainnya, seperti menonton film sebagai bekal untuk riset TV dan Film, atau mendengarkan musik sebagai inspirasi untuk menciptakan lagu. Efek sosiologis ini memberikan polarisasi bahwa individu selalu berinteraksi secara intrepersonal dalam memusatkan kegiatan yang bermanfaat dan dapat menjadi pendukung aktifitas lain. Disamping itu, contoh lainnya, dalam efek primer dari pengalaman individu dalam membeli paket data unlimited memiliki beberapa faktor pendukung yang dapat diguankan dalam analisis ekonomi pengalaman yaitu bahwa paket data unlimited (kasus DKI Jakarta), memiliki sejumlah faktor pendukung pilihan Individu yaitu bahwa faktor psikologis dan faktor kepribadian merupakan dua faktor yang dominan berefek dalam pilihan pemenuhan kebutuhan Indiviu dalam paket data unlimited (Noviyarto, 2010). Sebagai pertimbangan selanjutnya, digunakan metode kualitatif mengguanakn teoritisasi data secara kualitatif, apabila dianalisis, maka dalam metode kuantitatif terutama dalam uji hipotesis Achmad 
(2016) meneliti mengenai model keperilakuan atas konsumsi produk bajakan didapatkan hasil bahwa secara parsial, melek finansial, sosialisasi orang tua dan kontrol diri berpengaruh positif terhadap perilaku menabung, sedangkan pengaruh teman sebaya tidak berpengaruh signifikan terhadap perilaku menabung. Perilaku menabung selain memiliki unsur ekonomi, juga memiliki unsur pengalaman individu dalam mengumpulkan sumber daya. Dalam hal ini dapat diambil makna, ekonomi pengalaman pun dapat menghadirkan perspektif interdisiplin melalui perbandingan perilaku atas penelitian lainnya, walau masih terlihat abstrak, namun pendekatan ini secara tidak langsung menjadi unsur pendukung kategorisasi data pada penyeusun kategori inti dan kategori pendukung apabila dilakukan penelusuran secara sosiologi dan secara keprilakukan.

Adapun rumusan masalah sebagai dasar penulisan ini adalah metodologi terbarukan apa yang dapat digunakan dalam menyusun pendekatan kualitatif untuk meneliti ekonomi pengalaman (sebagai kepentingan prinsip ekonomi dan kebutuhan manusia atas pengalaman dan hiburan). Penulisan ini pun bertujuan untuk menemukan model memo dan diagram dengan menggunakan studi kasus pengalaman Individu dalam penggunaan media daring secara umum (dengan fokus pada penggunaan internet dan fitur pada sejumlah aplikasi) pendekatan lain pula dibatasi dengan pengukuran kualitatif melalui pihak penyedia media daring dan aplikasi, sehingga jumlah output dan profit media daring dan aplikasi merepresentasikan perilaku konsumen dalam penggunaan media darin dan aplikasi tersebut.

\section{B. Metode Penelitian: Teoritisasi Data}

Teoritisasi data yang baik adalah teori yang didapatkan melalui instrumen tertentu yang secara induktif dilakukan melalui penelitian sehingga dapat menjelaskan mengenai suatu fenomena tertentu. Sehingga teori tersebut dapat ditemukan, disusun dan dibuktikan kehandalan dan kesesuaiannya dengan sementara melakukan pengumpulan data yang sistematis melalui analisis data yang memiliki keterkaitan terhadap fenomena yang diamati. Dengan demikian, pengumpulan data, analisis, dan teori slaing terkait dan dalam hubungannya bersifat timbal-balik.

Teoritisasi data merupakan pendekatan penelitian kualitatif yang disusun oleh Glaser dan Strauss. Dalam teoritisasi datat dapat digunakan perinsip-perinsip teknik dan prosedur yang diuraikan dalam beberapa literatur pada Glaser dan Strauss. Peneliti tidak memulai penyelidikan dengan satu teori tertentu lalu membuktikannya. Namun dengan suatu bidang kajian dan hal-hal terkait dengan bidang tersebut (pendekatan teori, survei atau jejak literature). Teori yang bersifat grounded yang bisa diakui sebagai tersusun dengan baik adalah dengan menerapkan suatu fenomena dengna memenuhi empat kriteria yaitu; (1) kesesuaian, (2) pemahaman, (3) generalitas, dan (4) kontrol (Strauss \& Corbin, 2003). Maka dapat diartikan bahwa ketika suatu karakteristik teori dapat sesuai dengan kenyataan sehari-hari secara cermat dalam beragam data, maka 
teori ini sangat relevan dengan daing nyata tersebut. Teoritisasi data dapat digunakan dengan sebaikbaiknya di berbagai disiplin ilmu yang diperlukan hanyalah prosedur, dan prosedur itu tidak terikat oleh disiplin ilmu tertentu (Strauss \& Corbin, 2003).

Dalam melakukan teoritisasi data maka dikenal mengenai pengkodean berbuka, berporos dan berpilih. Pengkodean berbuka meruapkan proses menguraikan, memeriksa, membandingkan, mengkonspekan, dan mengkateogrisasikan data (Strauss \& Corbin, 2003). Sebelumnya kita dapat memahami terlebih dahulu megnenai definisi operasional dari konsep dan kategroi. Konsep adalah label konseptual yang diatributkan pada kejadian, peristiwa, dan contoh fenomena diskrit lainnya, sedangkan kategori adalah klasifikasi dari konsep (Strauss \& Corbin, 2003). Klasifikasi konsep ini dimaksudkan bahwa dilakukannya pembandingan antara hubungan fenomena ketika konsep sedang dibandingkan. Dengan begitu, konsep tersebut dikelompokan bersama di bawah suatu konsep yang lebih abstrak yang berada di urutan atasnya disebut sebagai suatu kategori. Selanjutnya pemahaman mengenai pengkodean. Dalam pengkodean berbuka, peneliti melakukan label konseptualn yang dilengkapi pada kejadian, peristiwa dan contoh-contoh fenomena yang bersifat diskrit. Selain itu dilakukan kelasifitkasi konsep dengan melakukan analisis keterhubungan, sehingga konsep dikelompokan pada urutan abtrak yang berkategori.

Pengkodean berporos merupakan seperangkat prosedur penempatan data kembali dengan cara-cara baru setelah pengkodean berbuka, dengan membuat kalitan antar kategori. Ini dilakukan dengan memanfaatkan paradigm pengkodean yang mencakup kondisi, konteks, strategi aksi/interaksi, dan konsekuensi (Strauss \& Corbin, 2003). Dalam pengkodean berporos dikenal model paradigm yang digunakna untuk menghubungkan dengan kategori dalam sejumlah hubungan, yang menunjukan kondisi kausal, fenomena, konteks, kondisi pemengaruh, strategi tidnakan/interaksi, dan konsekuensi (Strauss \& Corbin, 2003). Dalam membentuk pendekatan yang terbaik untuk identifikasi kualitatif, maka berikut adalah contoh dari model paradigma yang digunakan untuk mengidentifikasi model ekonomi pengalaman, yaitu sebagai berikut:

\section{A. Kondisi Kausal B. Fenomena C. Konteks D.} Kondisi Pemengaruh E. Strategi Aksi/Interaksi F. Konsekuensi

Dengan menggunakan model paradigm ini maka peneliti dapat memikirkan data secara sistematis untuk menghubungkannya dengan cara yang sangat kompleks. Ketiga, terdapa pengodean berpilih, merupakan proses pemilihan kategori inti, pengaitan kategori inti terhadap kategori lainnya secara sitematis, pengabsahan hubungannya, mengganti kategori yang perlu diperbaiki dan dikembangkan lebih lanjut (Strauss \& Corbin, 2003). Hasil dari penggunaan pengkodean ini dapat membentuk penggabungan konsep dan data secara sistematis sehingga dapat merepresentasikan fenomena sosial di kehidupan sehari-hari dengan terbentuknya kategori 
Jurnal Pemikiran Sosiologi Volume 7 No.2 2020

Model Ekonomi Pengalaman: Memahami Perilaku Konsumen dan Layanan Konten Berbayar

Muhamad Ferdy Firmansyah

inti yang menghubungkan semua kategori utama, baik secara kategori inti maupun antar kategori.

Memo adalah catatan tentang analisis yang berhubungan dengan perumusan teori, sedangkan diagram merupakan penyajian hubungan antarkonsep secara visual (Strauss \& Corbin, 2003). Dalam memo yang digunakan untuk penelitian kualitatif berbasis teorititsasi data maka digunakan catatan kode, catatan teoritik dan catatan operasional. Dalam penyusunan metode kualitatif ini tidak perlu memasukan semua jenis catatan untuk meningkatkan kepekaan teoritik, namun dapat digunakan seperlunya guna membentuk kesinambungan model pendekatan kualitatif yang baik. Sedangkan dalam diagram, dalam teoritisasi data terdapat diagram logika dan diagram integratif, keduanya dapat digunakan dalam analisis kualitatif yang sistematis dan baik. Setiap analisis yang menggunakan memo dan diagram dapat dikembangkan secara bebas oleh peneliti, seperti menggunakana program komputer, kartu kode warna, map ataupun buku catatan dan metode yang digunakan tidaklah begitu penting namun harus memiliki manfaat dan memiliki penulisan yang teratur, progresif, sistematis serta mudah diperoleh kembali untuk keperluan penyortian dan referensi silang (Strauss \& Corbin, 2003).

Dalam penulisan ini, penulis mengembangkan model penelitian berbasis teoritisasi data dalam Strauss \& Corbin (2003) yang dikembangkan lagi untuk memudahkan penelitian sosial dengan beberapa pembagian tahapan prosedur sebagai berikut:

- Identifikasi Fenomena, Kepekaan Teoritik dan Penggunaan Literatur

- Prosedur Pengkodean Berbuka, Berporos dan Berpilih

- Penyusunan Matriks Kondisional dan Penyampelan Data

\section{Ekonomi Pengalaman dan Perilaku Manusia}

Ekonomi pengalaman merupakan studi interdisiplin mengenai analisis individu secara intrapersonal dalam memenuhi kebutuhan rohanian dan jasmaniah dalam bentuk jasa, dengan harapan untuk mendapatkan kepuasan yang maksimal dalam pengadaan layanan jasa yang memiliki unsur pengalaman penggunaannya, itu adalah deskripsi bebas mengenai ekonomi pengalaman dalam penulisan ini. Sebagai contoh, ekonomi pengalaman menganalisis mengenai tingkat kunjungan bioskop bagi sejumlah penduduk yang memiliki rasionalitas pilihan daripada menonton konser di lapangan terbuka, atau analisis mengenai pembelian data kuota untuk memenuhi gairah berseluncur di media sosial. Itu semua merupakan pemenuhan kebutuhan, yang dianalisis melalui perilaku manusia, dan memiliki unsur ekonomi yang diciptakan atas kegiatan berunsur pengalaman. Analisis mengenai ekonomi pengalaman mengedepankan kasus feonomena baik secara perbandingan (perbandingan minat menonton bioskop dengan minat menonton konser) atau kasus fenomena secara tunggal (analisis faktor pendukung 
pengalaman berseluncur di media sosial). Studi ini memiliki fokus untuk melihat efek intrapersonal dari aktivitas jasa yang dilakukan, aktivitas yang meningkatkan pemahaman pengalaman dan dapat diukur selaras dengan konsep kepuasan (utility).

Manusia mulai merasakan perubahan dan kebutuhan-kebuthan lain maka tumbuh perekonomain industri yang melahirkan upaya kesejahteraan manusia atas sumber daya yang perlu seminimal mungkin digunakan untuk menghasilkan manfaat sewajarnya dari usaha yang diberikan, selain itu analisis pertumbuhan ekonomi diperlukan dalam pertambanan modal, tenaga kerja dan upaya peningkatan produktifitas (Lankauskiene, 2015). terkenal atas acuan pada Adam Smith dalam "An Inquary Into The Nature and Causes of The Wealth Nation". Manusia mulai memberikan perhatian pada faktor pemuas kebutuhan yang tak benda, muncullah aktifitas perbankan atas jasa penyimpanan harta kekayaan yang berkembang sebab-akibat terhadap ahli keuangan dan moneter, melahirkan John Maynard Keynes dan Milton Friedman didalamnya. Dan perhatian muncul ketika B. Joseph Pine II dan James H. Gilmore memperkenalkan pemaparan mengenai The Experience of Economy: Past, Present and Future. Pine memberikan pembagian atas struktur ekonomi terhadap perekonomian agraris, industri, jasa, pengalaman dan transformasi yang diikuti oleh variabel pengikat dalam Primary Economic Offering, Economic Function, Nature of Offering, Extent of Use, Character, Development Method, Production Method, Delivery Method, Marketed Attributes, Basis of Purchase, Obervability, Primary Flows, dan
Information Content Level (Pine II \& Gilmore, 1999). Pine telah memberikan arah pada maksud dari ekonomi pengalaman dalam cuplikan bukunya yaitu:

"Experience - memorable events that engage each individual in an inherently personal way, such as going to a musical concert, thearitrical play or athletic event; visitng a museum, art gallery or far-off destination; ... we have now entered an experience economy, where experiences supplant services as the predominant economic offering in terms of GDP, employment and especially actual value. This progression of economic value, as we call it, can be seen ... and outlines how the locus of economic activity - what is bought and sold in the market place - has changed over the centuries."

(Pine II \& Gilmore, 1999)

Perilaku manusia merupakan salah satu studi yang menarik untuk disimak, ini berkaitan dengan rasionalitas pilihan. Semua studi mengenai ekonomi memiliki fokus untuk mendeskripsikan perilaku manusia, terutama dalam memenuhi kebutuhannya. Ekonomi perilaku memiliki fokus untuk memahami kegiatan manusia dalam pemenuhan standar teori ekonomi dan pengujian secara bias dan berkelanjutan yang dapat memberikan gambaran dalam damapak untuk perilaku dan pilihan-pilihan dalam ekonomi (Central Expentiture Evaluation Unit, 2014). Maka ekonomi perilaku memiliki fokus dalam the rationalagent model. Dalam sejumlah pemodelan ekonomi perilaku dikenal dengan analisis pemilihan bias dan berkelanjutan perilaku (selected biases and behavioural influences) diantaranya memiliki sejumlah contoh bias and influences yaitu seperti 
Jurnal Pemikiran Sosiologi Volume 7 No.2 2020

Model Ekonomi Pengalaman: Memahami Perilaku Konsumen dan Layanan Konten Berbayar

Muhamad Ferdy Firmansyah

cognitive limitations, defaults, present bias/timeinconsistency/hyperbolic discounting dan lainnya. Adapun sebagai studi interdisiplin, ekonomi perilaku dalam kritik memiliki konstruksi dan pengujian teori ekonomi untuk membentuk asumsi model yang realistis dan mudah dipahami. Ini merupakan salah satu asumsi bahwa ekonomi perilaku berdasarkan perspektif adalah sangat penting untuk membentuk model guna membuat analisis prediksi yang baik dalam analisis dan penjelasan mengenai output sosialekonomi (socioeconomic), dengan signifikan keilmuan tertentu, dan mempertimbangkan asumsi psikologi juga mempertimbangkan asumsi institusi relevan dan sosiologi (Altman, 2008).

Dalam ekonomi perilaku erat kaitannya dalam memahami pilihan rasional seorang individu dengan studi ilmu lain (psikologi dan sosiologi), lalu bagaimanakah penelitian berbasis psikologi dan sosiologi ini dapat digunakan para peneliti untuk membentuk model ekonomi dalam pembentukan pilihan rasional invidu?. Dalam ekonomi perilaku, kombinasi dari asumsi yang digunakan dan beririringan dengan aturan institusi serta mempertimbangkan alokasi dan harga dalam menitikberatkan pengaruh ekonomi di dalamnya (Camerer, A., \& Axline, The Behavioral Challenge to Economics, 2003).

\section{Penggunaan Layanan Konten: Era Digital dan} Kemudahan Yang Menuntut Anda Membayar

Memasuki era reformasi di Indonesia, pilihan konsumsi masyarakat mulai beragam. Setidaknya dalam waktu 20 tahun (terhitung 1999) konsumsi masyarakat Indonesia terhadap layanan jasa digital semakin besar, kepemilikan smartphone meningkat, dan penggunan internet dari tahun ke tahun mengalami peningkatan. Ekonomi digital di Indonesia merupakan suatu sekor pengembangan perekonomian yang menjanjikan dan peluang menjanjikan menuju negara maju melalui digitalisasi di bidang ekonomi. Hingga 2025, e-commerce diproyeksikan tumbuh 290,5\% menjadi US\$ 82 miliar. Sektor online travel juga mencatatkan pertumbuhan meskipun tidak sebesar e-commerce. Pada 2019, nilai GMV online travel sebesar US\$ 10 miliar. Nilai tersebut meningkat hingga 100\% dari 2015 yang sebesar US\$ 5 miliar. Pada 2025, diproyeksikan online travel memiliki GMV sebesar US\$25 miliar atau meningkat 150\% dibandingkan 2019. Sektor berbagi tumpangan (ride hailing) juga mengalami kenaikan yang signifikan, yaitu sebesar 566,7\% dari US\$ 900 juta menjadi US\$ 6 miliar. Selain itu pada 2015, sektor ride hailing diprediksikan meningkat $200 \%$ menjadi US\$18 miliar. Terakhir merupakan sektor online yang merupakan sektor yang memiliki kontribusi yang akan semakin meningkat kedepannya.

Pada 2015 tercatat nilai GMV media online sebesar US\$ 600 juta, yang kemudian meningkat 566,7\% menjadi US\$ 4 miliar. Pada 2025, diproyeksikan nilai GMV media online sebesar US\$ 9 
Jurnal Pemikiran Sosiologi Volume 7 No.2 2020

Model Ekonomi Pengalaman: Memahami Perilaku Konsumen dan Layanan Konten Berbayar

Muhamad Ferdy Firmansyah

miliar atau meningkat 125\% dari 2015 (Jayani, 2019).

Dalam ilmu ekonomi selintas kita mengenai mengenai fungsi konsumsi dan penggunaan asumsinya terhadap pandangan penulis dalam ekonomi pengalaman. Dalam ekonomi makro pendapatan masyarkaat suatu negara seara keseluruhan (pendapatan nasional) dialokasikan ke dua kategori penggunaan, yaitu pendapatan $\mathrm{Y}$, sedangkan konsumsi dilambangkan $\mathrm{C}$ dan tabungan dilambangkan S (Dumairy, 2007).

Adapun apabila kita ingin mengidentifikasi potensi penggunaan layanan konten melalu meda daring yaitu dapat dijelaskan melalui gambar berikut:

Gambar 01. Potensi Ekonomi Digital Indonesia 20152025

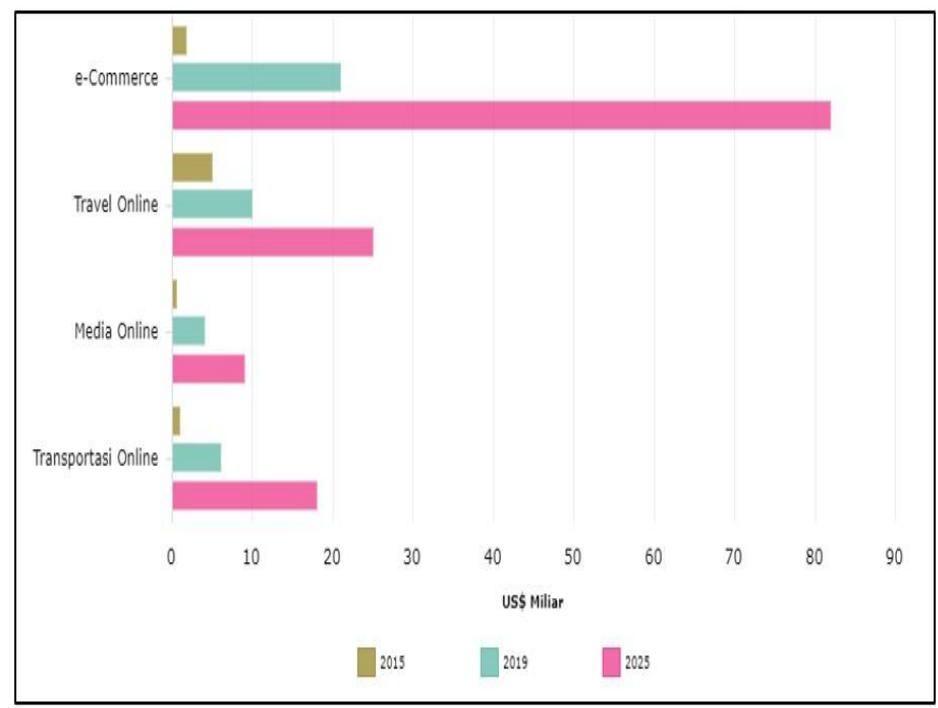

Sumber: Dwi Hadya Jayani dalam artikel "Inilah Potensi Ekonomi Digital Indonesia 2015-2025"

$\mathrm{Y}=\mathrm{C}+\mathrm{S}(1)$
Dalam persamaan ini dapat kita ketahui bahwa yang mempengaruhi pendapatan $\mathrm{Y}$ adalah sebarapa bauran alokasi dari konsumsi masyarakat, yang sisanya akan menjadi tabungan untuk investasi masa depan dengan berbagai motif (berjaga-jaga atau spekulasi). Fungsi konsumsi menjelaskan hubungan antara konsumsi dan pendapatan nasional, yang secara umum dirumuskan sebagai berikut (Dumairy, 2007):

$\mathrm{C}=\mathrm{f}(\mathrm{Y})=\mathrm{C}_{-} 0+\mathrm{cY}(2)$

Konstanta C_0 menunjukan besarnya konsumsi nasional pada pendapatan nasional sebesar nol; mencerminkan konsumsi nasional maksimum (autonomous consumption, konsumsi otonom), yang pasti ada dan harus terpenuhi dari seorang individu, meskipun dalam keadaan pendapatan nasional nol. Secara grafik, C_0 merupakan penggal kurva konsumsi pada sumber vertikal C (Dumairy, 2007). Koefisien c mencerminkan bearnya tambahan konsumsi sebagai akibat adanya tambahan pendapatan nasional pada jumlah tertentu. Dalam bahasa ekonomi, c adalah Marginal Prospensity to Consume (Dumairy, 2007). Secara grafik, c merupakan lerang dari kurva konsumsi.

\section{Dalam ekonomi pengalaman penulis} memberikan pertanyaan pada pembaca yang tertarik untuk melakukan riset dalam ekonomi pengalaman, yaitu, apakah kebutuhan gawai dalam diri individu masih akan dikategorikan masuk pada tambahan konsumsi (koefisien c) atau bisa dalam beberapa 
Jurnal Pemikiran Sosiologi Volume 7 No.2 2020

Model Ekonomi Pengalaman: Memahami Perilaku Konsumen dan Layanan Konten Berbayar

Muhamad Ferdy Firmansyah

decade kedepan menjadi salah satu kebutuhan primer (yang mempengruhi $\mathrm{C}_{-} 0$ )?

Dengan mempertimbangkan pembangunan blok dalam analisis teori ekonomi dan alternatif pendekatan analisis perilaku, maka dalam membentuk model ekonomi pengalaman dalam kasus layanan konten menggunakan blok analisis self interest dengan alternatif analisis perilaku yaitu social utilities (Camerer, A., \& Axline, The Behavioral Challenge to Economics, 2003).

Dalam kasus ini, akan diteliti secara kualitatif dengan menggunakan metode pendekatan baru dalam teoritisasi data dengan mengikuti data operasional analisis sebagai berikut:

Tabel 1. Indentifikasi Kausal, Fenomena dan Pendekatan pada Ekonomi Pengalaman

\begin{tabular}{|c|l|l|l|}
\hline No. & \multicolumn{1}{|c|}{ Kausal } & \multicolumn{1}{|c|}{ Fenomena } & Pendekatan \\
\hline 1. & $\begin{array}{l}\text { Individu menggunakan layanan konten } \\
\text { tanpa adanya pungutan dalam } \\
\text { pemakaian }\end{array}$ & $\begin{array}{l}\text { Penggunan Gratis Layanan } \\
\text { Konten }\end{array}$ & $\begin{array}{l}\text { Ekonomi } \\
\text { Perilaku }\end{array}$ \\
\hline 2. & $\begin{array}{l}\text { Indiviu melakukan pembayaran } \\
\text { terhadap layanan konten yang } \\
\text { digunakan }\end{array}$ & $\begin{array}{l}\text { Pengguna Berbayar Layanan } \\
\text { Konten }\end{array}$ & $\begin{array}{l}\text { Ekonomi } \\
\text { Perilaku }\end{array}$ \\
\hline 3. & $\begin{array}{l}\text { Individu secara psikologi mendapatkan } \\
\text { tekanan dan dorongan untuk } \\
\text { mendapatkan layanan konten }\end{array}$ & $\begin{array}{l}\text { Faktor Internal Pemilihan } \\
\text { Layanan Konten }\end{array}$ & Psikologi \\
\hline 4. & $\begin{array}{l}\text { Individu secara sosiologi mendapatkan } \\
\text { tekanan dan dorongan untuk } \\
\text { mendapatkan layanan konten }\end{array}$ & $\begin{array}{l}\text { Faktor Eksternal Pemilihan } \\
\text { Layanan Konten }\end{array}$ & Sosiologi \\
\hline
\end{tabular}

Sumber: Dokumen Penulis

Setelah mendepatkan identifikasi kausal, fenomena maka selanjutnya untuk mengerucutkan pendekatan dengan pengkoden. Berikut adalah pengkodean berbuka untuk menentukan bauran data kualitatif yang diperlukan dalam membentuk model penulisan ekonomi pengalaman,

Tabel 2. Pengkodean Berbuka Terhadap Variabel Ukur pada Ekonomi Pengalaman

\begin{tabular}{|c|c|c|c|c|c|}
\hline No. & Fenomena & Kode & Sifat & Ukuran & $\begin{array}{c}\text { Kondisi } \\
\text { Pemengaruh }\end{array}$ \\
\hline \multirow{4}{*}{1.} & \multirow{4}{*}{$\begin{array}{l}\text { Penggunan Gratis } \\
\text { Layanan Konten }\end{array}$} & 1.a & Frekuensi & $\begin{array}{l}\text { Sering - Tidak } \\
\text { Sering }\end{array}$ & Waktu luang \\
\hline & & 1.b & Keluasaan & Banyak - Kurang & Spesifikasi konten \\
\hline & & 1.c & Intensitas & Tinggi - Rendah & Waktu luang \\
\hline & & 1.d & Durasi & Panjang - Pendek & Waktu luang \\
\hline \multirow{4}{*}{2.} & \multirow{4}{*}{$\begin{array}{l}\text { Pengguna Berbayar } \\
\text { Layanan Konten }\end{array}$} & 2.a & Frekuensi & $\begin{array}{l}\text { Sering - Tidak } \\
\text { Sering }\end{array}$ & Waktu luang \\
\hline & & 2.b & Keluasaan & Banyak - Kurang & Spesifikasi konten \\
\hline & & 2.c & Intensitas & Tinggi - Rendah & Waktu luang \\
\hline & & 2.d & Durasi & Panjang - Pendek & Waktu luang \\
\hline \multirow{4}{*}{3.} & \multirow{4}{*}{$\begin{array}{l}\text { Faktor Internal } \\
\text { Pemilihan Layanan } \\
\text { Konten }\end{array}$} & 3.a & Usia & 0 - (masa umur) & Kesehatan \\
\hline & & 3.b & Jenis Kelamin & $\begin{array}{l}\text { Laki-Laki - } \\
\text { Perempuan }\end{array}$ & Biologis, Hormon \\
\hline & & 3.c & Pendidikan & SD, SLTP, dst. & Potensi Belajar \\
\hline & & 3.d & Kesehatan & $\begin{array}{l}\text { Tidak Sehat - } \\
\text { Sangat Sehat }\end{array}$ & Perilaku Hidup Sehat \\
\hline \multirow{4}{*}{4.} & \multirow{4}{*}{$\begin{array}{l}\text { Faktor Eksternal } \\
\text { Pemilihan Layanan } \\
\text { Konten }\end{array}$} & 4.a & Teman Sebaya & Tidak Dekat - Karib & Komunikasi Teman \\
\hline & & 4.b & Keluarga & $\begin{array}{l}\text { Ayah, Ibu, Adik, } \\
\text { Kakak, Saudara }\end{array}$ & Komunikasi Keluarga \\
\hline & & $4 . c$ & Informasi & $\begin{array}{l}\text { Sederhana - } \\
\text { Kompleks }\end{array}$ & Sumber Informasi \\
\hline & & 4.d & $\begin{array}{l}\text { Kelompok } \\
\text { Referensi }\end{array}$ & Tidak Dekat - Karib & $\begin{array}{l}\text { Komunikasi } \\
\text { Kelompok }\end{array}$ \\
\hline
\end{tabular}

Sumber: Dokumen Penulis (kode disini adalah kode fenomena)

Dalam pengkodean berbuka masih memiliki pendalaman model yang abstrak sehingga dilakukan pengkodean berporos yang menggunakan pendalaman fenomena dengan dukungan catatan teoritik dan catatan operasional (bila diperlukan). Adapun dalam mengerucutkan analisis, didapat tabel sebagai berikut: 
Jurnal Pemikiran Sosiologi Volume 7 No.2 2020

Model Ekonomi Pengalaman: Memahami Perilaku Konsumen dan Layanan Konten Berbayar

Muhamad Ferdy Firmansyah

Tabel 3. Pengkodean Berporos Pre-Kategorisasi Model

\begin{tabular}{|c|c|c|c|c|}
\hline Fenomena & Pendekatan & \multicolumn{2}{|c|}{ Fase Hubungan } & $\begin{array}{c}\text { Kemungkinan } \\
\text { Analisis }\end{array}$ \\
\hline \multicolumn{5}{|l|}{ A. Kondisi Pengguna } \\
\hline $\begin{array}{l}\text { Penggunan Gratis Layanan } \\
\text { Konten }\end{array}$ & Ekonomi Perilaku & Fase 1 & Fase 2 & Kemungkinan 1 \\
\hline $\begin{array}{l}\text { Pengguna Berbayar Layanan } \\
\text { Konten }\end{array}$ & Ekonomi Perilaku & Fase 2 & Fase 1 & Kemungkinan 2 \\
\hline \multicolumn{5}{|l|}{ B. Kondisi Lingkungan } \\
\hline $\begin{array}{l}\text { Faktor Internal Pemilihan } \\
\text { Layanan Konten }\end{array}$ & Psikologi & Fase 1 & Fase 2 & Kemungkinan 1 \\
\hline $\begin{array}{l}\text { Faktor Eksternal Pemilihan } \\
\text { Layanan Konten }\end{array}$ & Sosiologi & Fase 2 & Fase 1 & Kemungkinan 2 \\
\hline
\end{tabular}

Sumber: Dokumen Penulis

Dalam tabel diatas dapat dijabarkan mengenai kemungkinan-kemungkinan analisis ekonomi pengalaman yaitu melalui kagorisasi komponen pengkodean berbuka, didatap kategori inti 1 yaitu kondisi pengguna dan kategori inti 2 yaitu kondisi lingkungan. Selain mendapatkan kategori inti dan kategori. Kemungkinan analisis adalah kemungkinan bagi penulis untuk memulai penulisan mengenai ekonomi pengalaman melalui kagori inti 1 atau kategori inti 2, ini memudahkan bagi penulisan selanjutnya untuk menganalisis secara kualitatif ekonomi pengalaman.

Selanjutnya dibentuk untuk penyusunan model kualitatif dengan pengkodean berporos, dalam hal ini akan dihubungkan setiap kategori inti, dan dengan membentuk kagetori utama dibawah kategori inti dan dapat menjelaskan keterkaitan mengenai hubungan tersebut. Berikut adalah keterikatan hubungan antara kategori inti dan kategori utama.
Hasil dari pengkodean adalah digunakannya penjelasan fenomena ekonomi pengalaman dengan dua kategori inti yaitu kategori pengguna dan kategori lingkungan, untuk penulisan ini hanya akan mendalami mengenai kategori pengguna dan kategori lingkungan hanya akan dijelaskan sejumlah variabel ukur dari catatan operasional yang didapatkan dan mempengaruhi kategori lingkungan. Dalam kaitannya mengenai catatan operasional, digunakan teknik pengkodean sederhana dengan menggunakan model Urutan Dokumen-Keterwakilan Variabel-BE (Behavioral Economic) atau sebagai contoh yaitu 1.1 $\mathrm{BE}, 2.1 \mathrm{BE}$ dan seterusnya.

Gambar 2. Matriks Kondisional Layanan Konten pada Ekonomi Pengalaman

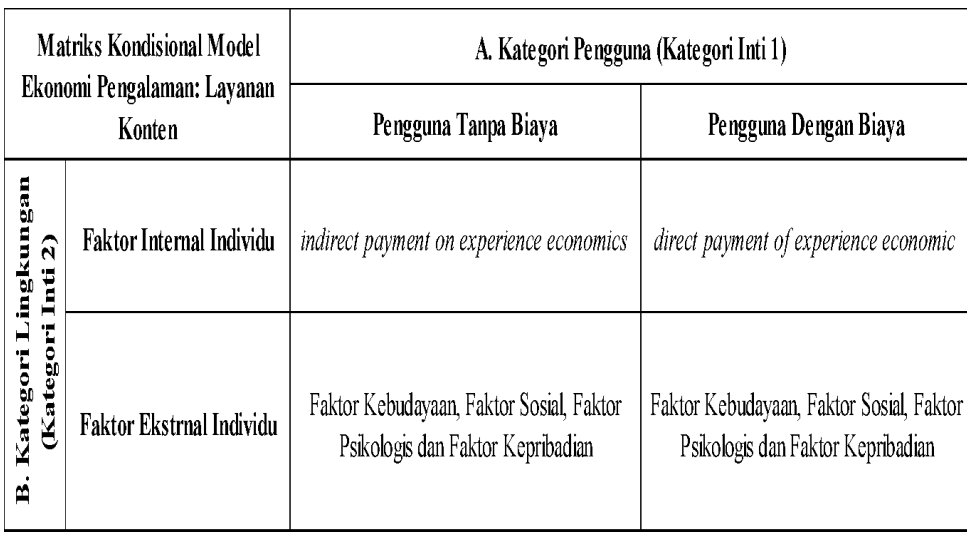

Sumber: Dokumen Penulis

Dari kategori inti 1 dapat kita dapat membagi dua bagian dari pengeluaran untuk kepuasan pribadi yaitu indirect payment dan direct payment. Indirect payment dalam ekonomi pengalaman ini adalah layanan-layanan digital yang dapat anda akses secara gratis (sehingga tidak mempengaruhi konumsi otonom anda) dalam periode yang tidak dibatasi, 
namun sebagai kontribusinya adalah anda menyuplai data pribadi dan kegiatan yang lebih sering (traffic internet) dari suatu layanan yang disediakan. Data yang anda kirim dan kegiatan yang polanya anda lakukan menjadi sumber pendapatan layanan tersebut sebagai bekal untuk data pasar dalam pembuatan bauran pemasaran. Dalam layanan indirect payment ini dapat kita ambil contoh yaitu google, facebook, twitter dan youtube. Anda seringkali berpikir kemana saya harus membayar segala macam pengalaman dari layanan-layanan yang mereka berikan secara gratis? Itu kembali kepada pendahuluan definisi dari indirect payment on experience economics (IPEE).

Dalam IPEE, tidak akan mengganggu angka konsumsi otonom Anda (dalam asumsi bahwa keberadaan layanan itu merupakan kebutuhan primer Anda dalam berinteraksi secara digital). Terdapat beberapa keuntungan pengalaman ekonomi yang didapat diantaranya (1) sebagai media penjualan, (2) sebagai pemuas kebutuhan/hiburan, (3) sebagai pekerjaan (youtuber yang berusaha meraih sebanyak mungkin subscribe). Sehingga IPEE memiliki korelasi positif terhadap peningkatan kepuasan tambahan (pendapatan). IPEE memiliki karakteristik bahwa, semakin banyak manusia itu adalah aset data untuk meraup keuntungan dari data yang diberikan. IPEE melihat bahwa membuat layanan nol rupiah bukan meruapkan satu kerugian, namun merupakan peluang luas dalam keuntungan mitra dan akses layanan lebih untuk mencakup manusia di seluruh dunia.
Tidak ada yang gratis dalam dunia ini, ini berlaku bagi pemberi layanan pengalaman yang bersifat direct payment. Konsepnya memiliki perbedaan dari IPEE, direct payment of experience economic (DPEE) menekankan kepada pemberian fitur tambahan yang dapat anda tukarkan dengan mengorbankan sejumlah biaya yang diperlukan oleh pemberi layanan. Sehingga terdapat tiga keuntungan pemberi layanan tersebut yaitu; (1) data pengguna, (2) traffic pengguna, dan (3) biaya untuk upgrade kepada akun premium. Umumnya dalam pemberian judul untuk akun premium merupakan strategi pemasaran untuk membatasi fitur gratis dan memberikan fitur luar biasa kepada pengguna akun premium. Ini umum digunakan kepada perusahaanperusahaan yang meluncur kepada pasar monopolistik (memiliki kriteria sejenis dan saling mempengaruhi satu sama lain, sangat rentan terhadap kebijakan dan inovasi yang dilakukan oleh penyedia layanan lainnya). Sebagai contoh dari para pemberi layanan DPEE adalah spotify (streaming music), Netflix (penyedia layanan film dan acara televisi berbasis streaming), konser musik dan bioskop.

DPEE memanfaatkan jumlah upgrade ke akun premium sebagai pendapatan tetap mereka (kecuali bioskop dan konser musik yang menjadikan penghasilan tiket sebagai yang utama). Pemberi jasa akan selalu memasang iklan dan tawaran-tawaran menarik dalam pemberian jasa layanan, ini merupakan strategi untuk mendapatkan keuntungan lebih dari pengguna, yaitu data pengguna sampai kepada transfer biaya upgrade, secara tidak langsung ini merupakan hal yang menguntungkan daripada 
melakukan skema IPEE, namun segmentasi nya berbeda. IPEE memiliki segmentasi luas menyeluruh karena memberikan layanan pengguna yang umum (search engine, email dan drive) sehingga dengan membatasi pengguna gratis akan berkorelasi negatif negatif terhadap pemberi layanan. Sedangkan DPEE lebih memiliki segmentasi yang lebih sempit daripada IPEE, DPEE mengandalkan tren pasar dan segmen tertentu (pecinta music atau pecinta anime) untuk mempertahankan pasar yang mereka bidik, karena segmen yang sempit maka memberlakukan akun gratis dan premium adalah hal yang menguntungkan daripada memiliki skema IPEE.

Adapun untuk kategori inti 2 yaitu kategori lingkungan adapun variabel yang mempengaruhi secara internal dan eksternal individu merujuk pada catatan teoritik. Catatan teoritik didapatkan sejumlah 6 hasil penelitian mengenai ekonomi perilaku dan perilaku konsumen dan membentuk kode $1.1 \mathrm{BE}$ sampai 6.1.BE dan dianalisis sehingga menghasilkan pembagian bagi variabel-variabel yang memiliki hubungan internal atau variabel-variabel yang memiliki hubungan eksternal. Adapun kode catatan teoritik untuk 5.1 BE dan 6.1 BE merupakan dua penulisan ilmiah yang menjelaskan mengenai meotodologi pendekatan penelitian pada ekonomi perilaku dan perilaku konsumen. Adapun hasil klasifikasi adalah sebagai berikut:
Tabel 5. Komponen Kategori Ukur pada Kategori inti 2: Kategori Lingkungan

\begin{tabular}{|c|c|c|}
\hline Kode & Komponen Kategori Ukur & Kategori \\
\hline \multirow{4}{*}{ 1.1.BE } & Jenis Kelamin & \multirow{13}{*}{ Internal } \\
\hline & Lama Aktivitas/ Jam Kerja & \\
\hline & Pendidikan & \\
\hline & Informasi & \\
\hline \multirow{4}{*}{ 3.1.BE } & Attention (perhatian) & \\
\hline & Interst (minat atau ketertarikan) & \\
\hline & Desire (hasrat atau keinginan) & \\
\hline & Action (tindakan pembelian) & \\
\hline \multirow{5}{*}{ 4.1.BE } & Motivasi & \\
\hline & Persepsi & \\
\hline & Belajar & \\
\hline & Kepribadian dan Konsep Diri & \\
\hline & Sikap & \\
\hline 2.1.BE & Faktor Kebudayaan & Eksternal \\
\hline
\end{tabular}

Sumber: Dokumen Penulis

Keuntungan Google yang berhasil memonopoli setidaknya $80-90 \%$ pasar search engine meraup keuntungan pada 2018 sebesar 31,15 miliar dollar AS sekitar 433 triliun rupiah (Pertiwi, 2018). Pendapatan ini naik 26 persen dibandingkan kuartal pertama tahun lalu. Disisi lain, laba per saham Facebook tercatat US $\$ 1,76$ (Rp 26.777) dibandingkan perkiraan Refinitiv US $\$ 1,47$. Pendapatan mencapai US $\$ 13,73$ miliar (Rp 208,9 triliun), lebih rendah dari US\$13,78 miliar yang diperkirakan Refinitiv di 2018 (Farras, 2018). Techcrush melaporkan, pada kuartal IV-2018, laba bersih (net income) Twitter tembus US\$244 juta atau setara Rp 3,42 triliun (asumsi US\$1=Rp 14.000,-). Dengan keuntungan ini, earnings per share Twitter US $\$ 0,33$ atau lebih tinggi dari ekspektasi analis sebesar US\$0,25 (Franedya, 2019). 
Jurnal Pemikiran Sosiologi Volume 7 No.2 2020

Model Ekonomi Pengalaman: Memahami Perilaku Konsumen dan Layanan Konten Berbayar

Muhamad Ferdy Firmansyah

Layanan musik Spotify telah berhasil meraup pengguna 100 juta orang pelanggan berbayar dari total 217 juta pelanggan pada 2019 (Cengka, 2019). Pendapatan dari pelanggan berbayar merupakan sumber penghasilan utama Spotify saat ini, dengan 1.385 juta euro berasal dari pelanggan Spotify Premium. Hanya 126 juta euro yang berasal dari iklan yang diperdengarkan untuk pelanggan gratisan. Disisi lain, Netflix, penyedia layanan film dan serial televisi mencatatkan pendapatan sebesar US\$4 miliar (lebih dari 600 triliun rupiah) pada kuartal III/2018. Dari sebelumnya US\$2,98 miliar seiring meningkatnya jumlah pelanggan. Laba bersih perusahaan yang bergerak dilayanan streaming konten melonjak hamper $211 \%$ dari US $\$ 129,6$ juta menjadi US $\$ 402,8$ juta (Margrit, 2018). Netlix mengklaim pelanggannya bertambah 7 juta dalam periode juli-september 2018 .

Harga tiket konser secara general terus mengalami kenaikan yang signifikan. Pada tahun 2017, harga rata-rata tiket konser global berkisar pada angka \$85. Angka ini kemudian melonjak menjadi $\$ 94.31$ pada 2018, yang berarti harga tiket konser tahunan mengalami kenaikan sebesar 10,95\%. Kenaikan harga ini bahkan melebihi tiga kali lipat inflasi Indonesia yang pada tahun 2018 berada pada angka 3,13\%. Melihat lebih jauh lagi ke belakang, Pollstar mempublikasikan data perkembangan inflasi dan harga tiket 100 konser terpopuler di Amerika Utara yang dimulai pada tahun 1996 hingga tahun 2018. Data menunjukkan bahwa terjadi inflasi sebesar 55,1\% pada tahun 2018 dengan tahun 1996 sebagai tahun dasar. Sedangkan harga tiket konser mengalami kenaikan sebesar empat kali lipatnya, yaitu 254,8\%.
Masifnya kenaikan harga tiket konser yang yang melampaui kenaikan komoditas-komoditas umum membuat tiket konser terasa semakin tak terjangkau bagi khalayak (Salensia, 2020).

Ekonomi pengalaman bukan untuk menjadikan suatu batasan atas perkembangan analisis ilmu ekonomi di lini studi lainnya, ini adalah kenyataan bahwa ilmu ekonomi memiliki sisi yang beragam dan dapat disesuaikan dengan kebutuhan pada saat ini. Maka dari itu di pendalaman selanjutnya kita akan mengetahui, dengan mengakses google, twitter, facebook, youtube, Spotify, Netflix, kita telah menyumbangkan banyak uang kita untuk kesejahteraan di negara lain. Maka sebagai konsumen kita mesti bijak dan sesegera mungkin menjauhkan diri dari belenggu kapitalisme ekonomi yang merupakan ancaman non-militer yang ada di Indonesia. Penulis rasa ini sulit namun mari kita coba dan bergerak menuju inovasi yang sesaui dengan kebutuhan Indonesia dan masyarakatnya yang plural. Kedepannya diharapkan mahasiswa ilmu ekonomi untuk dapat melihat perkembangan ilmu pengetahuan dan tidak terlalu takut untuk mengambil studi lintas jurusan dalam berbagai tulisan dan risetnya.

\section{E. Kesimpulan}

Dalam memahami berbagai dinamika sosial yang ada, setiap individu yang tercipta sebagai makhluk sosial memiliki kepentingan terhadap individu lain, makhluk hidup lain dan pada benda. Interaksi sosial memang tidak akan terwujud melalui 
Jurnal Pemikiran Sosiologi Volume 7 No.2 2020

Model Ekonomi Pengalaman: Memahami Perilaku Konsumen dan Layanan Konten Berbayar

Muhamad Ferdy Firmansyah

hubungan dengan benda, karena tidak adanya timbal balik komunikasi. Sehingga komunikasi pada benda merupakan komunikasi yang berkonsep intrapersonal (seperti seseorang yang berbicara pada diri sendiri, atau seseorang yang memikirkan sesuatu dengan pikirannya). Pengalaman merupakan interaksi individu dengan dirinya sendiri, atau interaksi secara intrapersonal. Komunikasi intrapersonal ini ada karena kebutuhan suatu individu untuk merasa senang, aman dan cukup.

Pengalaman tidak hanya memiliki perspektif untuk menjadikan individu senang, aman dan cukup, namun jauh dari hal itu dirumuskan sebagai hasil akhir yang diinginkan, pengalaman sejatinya adalah semua catatan langkah individu di muka bumi. Pengalaman muncul karena manusia hidup dan melangkah, melakukan interaksi sosial, bersosialisasi dan melakukan internalisasi nilai dan norma dari kelompok sosial yang dia ikuti. Disamping perspektif keingingan invididu dan perspektif bahwa pengalaman lahir karena manusia hidup dan berinteraksi, pengalaman menjadi salah satu kebutuhan, d alam ekonomi, kebutuhan adalah salah satu tujuan adanya ekonomi yaitu hidup secara cukup tanpa kekurangan dari kebutuhan-kebutuhan yang diinginkan dan dibutuhkan.

Dengan menggunakan pengkodean (berbuka, berporos dan berpilih) maka didapatkan model kategori inti dan katerogi utama yaitu terdiri dari 2 kategori inti. Adapun kategori inti pertama adalah kategori pengguna yaitu; (1) indirect payment on experience economics (IPEE) dan (2) direct payment of experience economic (DPEE), sedangkan kategori inti kedua adalah kategori lingkungan. Model ekonomi pengalaman dalam layanan konten ini dapat memberikan gambaran bagi sektor bisnis untuk melihat potensi segmentasi pasar yang cocok untuk sasaran layanan konten, disisi lain bagi pemerintah menajadi pertimbangan dalam regulasi dan pajak.

Adapun keterbatasan dalam penulisan ini adalah mengenai mesti ditingkatkannya kepekaan teoritik penulis untuk pendalaman penulisan dengan subjek sejenis kedepannya. Dengan peningkatan pemahaman atas kepekaan teoritik maka dapat meningkatkan pemahaman dan pemantapan hasil akhir perspektif yang didapat dalam konsep sosial untuk ekonomi pengalaman. Selain itu, keterbatasan lainnya adalah bahwa apabila penggunaan sumber daya literatur maka sebagai peningkatan kualitas catatan memo (baik catatan kode, catatan teoritik dan catatan operasional) maka diperlukan model penilaian bagi sumber literatur yang dapat menjaga kualitas sumber data literatur, diharapkan pada penulisan selanjutnya, perbaikan ini dapat dimuat untuk pengembangan konsep sosial pada ekonomi pengalaman dan konsep metodologi penelitian kualitatif berbasis teoritisasi data.

Sebagai kesimpulan, setidaknya dalam penulisan ini menghadirkan empat perspektif pemahaman ekonomi pengalaman terhadap sosiologi yaitu sebagai berikut. Pertama, perspektif ekonomi, ekonomi pengalaman memberikan bauran bagi dunia bisnis terutama yang bergerak di bidang jasa, dalam upaya mendapatkan keuntungan dalam permintaan 
atas sejumlah sektor hiburan. Kedua, perspektif interdisiplin, ekonomi pengalaman memiliki kaitan erat dengan ekonomi perilaku, namun ciri khas yang ada pada ekonomi pengalaman adalah bahwa ekonomi pengalaman menganalisis perilaku konsumen pada sektor hiburan dan jasa yang memberikan pengalaman bagi psikologis dan sosiologis seorang individu (perasaan dan interaksi sosial). Ketiga, perspektif pengukuran kepuasan maksimum, dalam perdebatan mengenai pengukuran ordinal dan cardinal dalam kepuasan konsumen, ekonomi pengalaman memberikan pendekatan lain bahwa kepuasan adalah efek kualitatif dari kegaitan hiburan dan jasa yang dilakukan seorang individu. Keempat, perspektif kebutuhan intrapersonal, ekonomi pengalaman lebih berpaku untuk mengidentifikasi emosional, perasaan dan komunikasi intrapersonal seorang individu dalam melakukan pilihan rasional dalam memenuhi kebutuhan hiburan dan jasa yang dikehendaki dan dibutuhkannya.

\section{Daftar Pustaka}

Acquisti, A., \& Grossklags, J. 2007. What Can Behavioral Economics Teach Us About Privacy? ETRICS 2006. Pensylvannia, USA: ETRICS.

Altman, M. 2008. Behavioral Economics, Economic Theory and Public Policy. Retrieved April 11, 2020

(https://papers.ssm.com/sol3/papers.cfm?ab stract_id=1152105).
Badan Pusat Statistika. 2018. Indikator Ekonomi November 2018: Buletik Statistika Bulanan. Jakarta: Badan Pusat Statistika.

Bank Indonesia. 2017. Memperkuat Momentum Menuju Pertumbuhan Berkelanjutan: Laporan Tahunan 2017. Jakarta: Bank Indonesia.

Camerer, C. F. 2003. The Behavioral Challenge to Economics: Undertanding Normal People. Retrieved April 10, 2020, (https://www.researchgate.net/publication/ 5027243_The_behavioral_challenge_to_econo mics_understanding_normal_people).

Camerer, C. F., A., R., \& Axline, L. G. 2003. The Behavioral Challenge to Economics. Conference Overview: How Humans Behave, Implications for Economics and Economic Policy (pp. 8-12). Boston: Federal Reserve Bank of Boston 48th Economic Conference.

Cengka, G. N. 2019. Pelanggan Berbayar Spotify Capai 100 Juta Orang. Retrieved April 11, 2020 (https://teknologi.bisnis.com/read/2019042 9/280/916965/pelanggan-berbayar-spotifycapai-100-juta-orang).

Central Expentiture Evaluation Unit. 2014. Behavioural Economics. Dublin, Ireland: Irish Government Economic and Evaluation Service.

Dharmmesta, B. S. 1999. Riset Konsumen Dalam Pengembangan Teori Perilaku Konsumen dan Masa Depannya. Jurnal Ekonomi dan Bisnis Indonesia. 
Jurnal Pemikiran Sosiologi Volume 7 No.2 2020

Model Ekonomi Pengalaman: Memahami Perilaku Konsumen dan Layanan Konten Berbayar

Muhamad Ferdy Firmansyah

Dumairy. 2007. Matematika Terapan untuk Bisnis dan Ekonomi. Yogyakarta: BPFE-Yogyakarta.

Farras, B. 2018. Facebook Raup Pendapatan Rp 209 T di Kuartal III-2018. Retrieved April 11, 2020, (https://www.cnbcindonesia.com/market/2 0181031124819-17-39908/facebook-rauppendapatan-rp-209-t-di-kuartal-iii-2018).

Franedya, R. 2019. Laba 2018 Tembus Rp 3 T, Bos Twitter Hanya Bergaji Rp 19.600. Retrieved April 2020, (https://www.cnbcindonesia.com/tech/2019 0409172838-37-65535/laba-2018-tembusrp-3-t-bos-twitter-hanya-bergaji-rp-19600).

Hidayat, R. 2003. Rasionalitas Semu dan Anomali Dalam Perilaku Ekonomi. Buletin Psikologi, 30-46.

Jayani, D. H. 2019. Inilah Potensi Ekonomi Digital Indonesia 2015-2025. Retrieved April 2020, 12 ,

(https://databoks.katadata.co.id/datapublish /2019/10/04/inilah-potensi-ekonomidigital-indonesia-2015-2025).

Laibson, D., \& A., J. 2015. Principles of Behavioral Economics. American Economic Review, 385390.

Lankauskiene, T. 2015. Economic Structure and Economic Growth Evaluation. Vilnius, Lithuania: Vilnius Gediminas Technical University.
Loewenstein, G. 2003. Emotions in Economics. Conference Overiew: How Humans Behave, Implication for Economics and Economic Policy (pp. 15-16). Boston: Federal Reserve Bank of Boston 48th Economic Conferece.

Margrit, A. 2018. Tingkatkan Penetrasi di Asia, Netflix Siapkan 17 Konten Orisinal. Retrieved April 11 , 2020

(https://teknologi.bisnis.com/read/2018110 8/105/857798/tingkatkan-penetrasi-di-asianetflix-siapkan-17-konten-orisinal).

Mizfar, F., \& Sinaga, A. 2015. Analisis Faktor-Faktor yang Mempengaruhi Perilaku Konsumen Dalam Pengambilan Keputusan Pembelian Kopi Instan. SEPA, 175-180.

Nofri, O., \& Hafifah, A. 2018. Analisis Perilaku Konsumen Dalam Melakukkan Online Shopping Di Kota Makassar. Jurnal Manajemen, Ide, Inspirasi (MINDS), 113-132.

Noviyarto, H. 2010. Pengaruh Perilaku Konsumen Mobile Internet Terhadap Keputusan Pembelian Paket Layanan Data Unlimited Internet CDMA di DKI Jakarta. InComTech, Junral Telekomunikasi dan Komputer, $107-$ 129.

Pertiwi, W. K. 2018. Pendapatan Perusahaan Induk Google Raup Rp 400 Triliun. Retrieved April 11 , 2020, (https://tekno.kompas.com/read/2018/04/2 4/18303147/pendapatan-perusahaan-indukgoogle-raup-rp-400-triliun). 
Jurnal Pemikiran Sosiologi Volume 7 No.2 2020

Model Ekonomi Pengalaman: Memahami Perilaku Konsumen dan Layanan Konten Berbayar

Muhamad Ferdy Firmansyah

Pine II, B. J., \& Gilmore, J. H. 1999. The Experience Economy. Boston: Harvard Business School Press.

Rohmah, H. H. 2016. New Media dan Perilaku Konsumen (Studi Korelasi Pengaruh Penggunaan Akun Instagram @md_store_hijab Terhadap Perilaku Membeli di Kalangan Mahasiswi Fakultas Ekonomi Angkatan 2011 Universitas Pembangunan Nasional "Veteran" Yogyakarta). Yogyakarta: Program Studi Ilmu Komunikasi, FISH, Universitas Islam Negeri Sunan Kalijaga.

Salensia, T. 2020. Meroketnya Harga Tiket Konser. Artikel Utama Ekonomi-Kanopi FEB UI.

Samson, A. 2016. The Behavioral Economics Guide 2016 (with an introduction by Gerd Gigerenzer). Retrieved April 10, 2020, (http://www.behavioraleconomics.com).

Shafir, E. 2003. Perception, Motivation, and Decision Making: An Overview. Conference Overview: How Humans Behave, Implications for Economics and Economic Policy (pp. 5-8). Boston: Federal Reserve Bank of Boston 48th Economic Conference.

Soekanto, S. 2009. Sosiologi Suatu Pengantar. Jakarta: Rajawali Press.

Strauss, A., \& Corbin, J. 2003. Dasar-Dasar Penelitian Kualitatif, Tata Langkah dan Teknik-Teknik Teoritisasi Data. Yogyakarta: Pustaka Pelajar.
Subianto, T. 2007. Studi Tentang Perilaku Konsumen Beserta Implikasinya Terhadap Keputusan Pembelian. Jurnal Ekonomi MODERNISASI, 165-182.

Subianto, T. 2007. Studi Tentang Perilaku Konsumen Beserta Implikasinya Terhadap Keputusan Pembeliannya. Jurnal MODERNISASI, 165182.

Syaiful, I. A., \& Sari, A. V. 2016. Faktor-Faktor yang Mempengaruhi Perilaku Konsumen dalam Bertransaksi di Media Sosial. PSIKOHUMANIORA: Jurnal Penelitian Psikologi, 95-112.

Warjiyo, P. 2016. Bauran Kebijakan Bank Sentral: Konsepsi Pokok dan Pengalaman Bank Indonesia. Jakarta: BI Institute.

Warjiyo, P. 2018. Sambutan Gubernur Bank Indonesia: Sinergi Untuk Ketahanan dan Pertumbuhan. Jakarta: Bank Indonesia.

Wigati, S. 2011. Perilaku Konsumen Dalam Perspektif Ekonomi Islam. Maliyah, 22-39. 